\begin{tabular}{l|l} 
& $\begin{array}{l}\text { Eastern } \\
\text { European } \\
\text { Countryside }\end{array}$ \\
\hline DOI: $10.2478 /$ eec-2014-0002 & $20^{\prime} 2014$
\end{tabular}

Ann-Mari Sätre ${ }^{1}$

\title{
Women in Local Politics in Russia: Coping with Poverty and Strategies for Development
}

\begin{abstract}
In historical continuation from the Soviet Union, social policy is predominantly a female responsibility. The present article focuses on women in local politics, who have an important role in local change, and who; among others, cope with poverty and try to solve reasons and consequences of poverty. Based on interviews and observations, the article shows how women's entrepreneurial skills of handling various shortcomings in the Soviet system are reflected in their present strategies for social development in local contexts in Russia. While the state leadership decides about reforms, setting new formal rules, local politicians develop their own routines and strategies. Being responsible for organising social welfare, interviewed female politicians told about how they use different strategies. This means that adopted practices are likely to be more heterogeneous than before. It seems important to both rely on useful norms inherited from the Soviet time, while also developing strategies based on new possibilities, arising as a result of reforms. The empirical data is based on interviews from three minor communities in one Russian region, conducted in 2002 to 2012.
\end{abstract}

Keywords: Russia, women, agency, strategies, local politics, poverty

\footnotetext{
1 The author greatly appreciates the research grant from the Swedish Research Council. I would like to express special thanks to Leo Granberg and Olga Pospelova for their valuable comments. Any omissions or errors are the sole responsibility of the author.
} 


\section{Introduction}

Today, local authorities in Russia are subject to an increased responsibility for job creation and survival at the local level. This is one effect of Russian reforms and it has been supported by the new law on local government of 2006, as well as, various national programs for local development. In effect, this also means that it is now up to the local level to find their own ways to deal with problems of poverty. The local strategies are developed against the background of socio-economic change. It appears that local policies deal with poverty issues through measures intended for the development of welfare and improvement in life conditions not in a general sense, but perhaps in relation to certain groups: the young, the unemployed, families with many children, or the like. The research idea behind this paper was to study, if, under which circumstances, and how a social change is possible in Russia. The paper acknowledges the importance of the local level in social change, arguing that permanent economic, political and societal changes can only take place when they reach and are carried on by people from the local level, from "other" or "second" Russia (Shanin and Nikulin 2012). The present paper focuses on women in local politics, who have an important role in local change, and who; among others, cope with poverty and try to deal with its reasons and consequences. As specific historical continuation from the Soviet Union, social policy was predominantly a female responsibility, and this is still the case in contemporary Russia.

The analytical frame of this paper was based on proposals of Douglass North (1990), who specifies four main kinds of institutions influencing the way a society develops: legal rules, organization forms, enforcement and behavioural norms. ${ }^{2}$ The agency dimension should be added to this list. The institutional approach is based on the assumption that informal institutions can prevent or delay the implementation of reforms. Survival of informal institutions is often perceived of as hindering development and change. Sometimes, however, they could facilitate change. One such feature is the 'entrepreneurial' skills of women, which they needed in the everyday life of Soviet Union, while trying to cope with poverty and; at the same time, lacking services. In many cases such skills have been preserved

\footnotetext{
${ }^{2}$ Institutions are all the restrictions that humans have created to form interaction in society (North 1990).
} 
and transferred to new generations, but the environment has changed. The main aim here was to analyze how the survival of women's entrepreneurial skills for the handling of shortcomings in the Soviet system is reflected in their strategies for social development in local contexts in Russia.

Important starting points for understanding historical changes during transition are Kornai's theory of the Soviet system as "economics of shortage" and the contributors to this theory (Kornai 1980; Davis 1988, 1989; see Sätre 1994). However, the aim of this paper was to study, not only these explanations for continuance of history, but; first and foremost, possibilities of changing it. Therefore, agency and its interaction with contextual structures is a crucial research topic, developed by Amartya Sen (1989) in his capability approach. Based on these assumptions, in the present paper, the focus was on women's strategies at the local political level. By using "strategy" word, it was indicated that it is a matter of planning and not just solutions for a day. ${ }^{3}$ These strategies are directed to solve everyday problems of the local population who lives on the edge of poverty by providing the basic infrastructure that is needed at the very local level. In addition to the theoretical analysis, the arguments and findings of this paper were based on observations and interviews conducted between 2002 and 2012 in three minor communities in Russia. The interviews with politicians at the community level and their counterparts at the lowest political level on their experiences of and views on local social welfare issues in post-Soviet Russia were used. As many of those politicians requested anonymity, the location of the study was not specified.

The paper starts by providing a brief background to women's role in politics. There are two kinds of consequences from the Soviet system that are relevant to the present paper: women's basic responsibility for social welfare and the continuation of the resource based economy, which in itself defines the circumstances within which local politics can operate. Given this background, the effect of some legal changes was discussed. Then the survival of norms, and how they might facilitate development, was analyzed. Finally, the paper identified dimensions of agency and strategies

\footnotetext{
3 The vice-mayor of a community with responsibility for social welfare expressed this ambition clearly: "I don't want developments to be the result of a coincidence of happenings, I want them to be the result of careful planning" (Interview, May 28, 2011).
} 
for development. Local politicians' strategies were analyzed by referring to their use of new and old resources, rights and relations, respectively.

\section{Second Russia}

The present paper aimed at highlighting some development trends outside the metropolitan areas. By following the development through regular visits in some smaller places, the study attempted to identify some tendencies that could increase our understanding of what the situation might look like for a large part of Russians. In the present context, "Second Russia" refers to: society outside of political or business elites and high priority sectors of economy (compare Shanin and Nikulin 2012: 7-8). The ambition here was to acknowledge the importance of the local level in social change, arguing that permanent political and societal changes can only take place when they reach and are carried on by people from the "second" Russia. Economically, such societies are in different ways dependent on local resources. Culturally, people are outsiders in relation to the high politics and national decision-making on distribution or redistribution of the nation's economic resources. A feeling of being an outsider and disinterest in politics characterise many of them. In this research, secondness was studied in the context of transition. Second Russia refers to local people in low-priority sectors, having to adapt themselves in the transition process.

Therefore, although these are places with little access to profits from priority branches, they simultaneously of relatively high level of freedom in terms of interference from the central level: 'you just have to be active and try, and try again, not to let bureaucracy let you down'. Sometimes, decentralization without allocation of resources from the central level is referred to as centralization; thus, in fact, arguing that local space has diminished. The present paper was focused on the opposite tendencies. There are now new possibilities for individuals and local firms thanks to an access to resources, along with central funds for local development and social programs, from which the local level can apply for resources.

After eight years in the same profession, a local politician was able to see the difference:

'With your own budget it is more interesting as we are more powerful to implement measures. More people get access to running water, some roads 
have been improved, and there are streetlights now in some villages. They are building a hospital, which is financed by the region and the state after the application has been submitted by the community. They built a beautiful walking bridge, and I am so happy that we are able to secure that any constructions that are made should be steady, stable and beautiful. This is something I have argued a lot about with men.' (interview, October 2008)

One can argue that there is, from time to time, opening space for development. Specifically, the aim of the study was to analyze possible strategies at the local level to benefit from such openings and to lift quality of everyday life in second Russia.

\section{Women's roles in politics from Soviet to Putin: surviving norms versus changing attitudes to poverty}

In Soviet ideology, poverty was associated with a failure of a society. Consequently, poverty as a general problem did not exist officially in the country. Secondly, the Soviet ideology identified poverty as a social phenomenon associated with deviant groups. In the 1990s, in the aftermath of the perestroika process, the pressure on social welfare provision increased considerably. The state no longer guaranteed jobs. Furthermore, there was a reduction of free education, free health and other social services, while the work places no longer were obliged to provide housing, child care etc. Along with the occurrence of new groups of poor people, poverty thus became acknowledged as a kind of new phenomenon related to reforms.

It is well-documented that female politicians commonly were responsible for social policies in the Soviet Union, and that women continue to take this responsibility at all political levels in post-Soviet Russia (Lapidus 1975; Clements 2002; Shevchenko 2002). Even the highest ranking women as vice-governors in 2006 oversaw policy areas traditionally reserved for women: education, culture, social policy and tourism (Moses 2008).

On the other hand, a changing attitude towards poverty and poor people has been noted. In the 1990s when 'almost everybody' was poor it was considered legitimate to be poor. Different stories of how difficult life was in the early perestroika years can be heard today. Recalling her job of being responsible for social affairs during the 1990s as her 'most difficult job ever', a former vice-mayor remembered all the drinking, thefts and 
criminality in the 1990s (interview October 28, 2008).Women suffered and her job was very much about defending women and children. At that time, there were strikes as people did not get salaries on time. She told about how she had to handle desperate and hungry people. "Due to the lack of money, they were paid in the form of bread, butter, products, furniture, lamps or whatever was available."

After the chaotic perestroika years, the economy started to recover after the turn of the century, however, old patterns seem to reappear; it has become socially unacceptable to be poor (Chebankova 2010). One could talk about a revival of the norm from the Soviet time saying that poor people are unworthy of support as they do not want to work, or they are just lazy or incompetent (Khlinskaya Rockhill 2010). This change in attitude towards the poor was reflected in interviews. In 2011, the local head of social services described how some are so lazy that they do not even grow their own plot, stealing from the neighbor instead (interview May 30, 2011). Also the vice-mayor in 2012 expressed the view that people are poor because they drink or simply do not want to work. 'There are jobs, but some people simply prefer to live on subsidies, nobody wants to perform heavy work like picking flax'(interview May 12, 2012). ${ }^{4}$

The tolerance towards difficulties to find solutions reflects a similar change in relation to attitudes towards poverty. A former vice-mayor described those lead-off people who have problems as 'being incompetent'. The mentality of previous years 'everything is impossible' has changed to a general attitude that 'everything depends on you'. She described how in the 1990s she was the one who 'had to confront all the protests and despair from local people who did not get their wages..., of course the situation is completely different now' (interview May 2012).

On the local level, this changed view is reflected in the various local development programs that aim at improving everyday life of the local population, thus reducing poverty in an indirect way (Sätre 2007). In 2012, a vice-mayor emphasized that poverty is the responsibility of the state:

4 A state system of subsidies for single parents, families with many children, people with disabilities and pensioners was introduced in the Soviet Union in 1974 (see Yates 2004). In the 1990s this system was expanded to also include new groups of the poor (Iarskaia-Smirnova and Romanov 2002). 
'Social services is part of the state, they decide who is entitled to support, who is classified as poor (maloimushchie), and; thus, how to distribute benefits; this money comes from the federal level. The community can pay for transport to the hospital for somebody from distant places or for a pregnant woman, given that the person is classified as entitled to support. We build houses for social living and pay for weak elderly. Then we have programs for preventing infant mortality, for rehabilitation of mentally sick children, for whom we can get support from rich individuals or firms.' (interview May 2012)

Consequently, it appears that local policies deal with poverty issues through measures intended for the development of welfare and improvement in life conditions in a general sense, but perhaps in relation to certain groups; the young, families with many children, or the like (interviews 2011-2012). Local politicians try to find space for their actions, not only to cope with everyday problems of poverty but also to construct strategies, and to reach more satisfying economic and social circumstances in the future. The following section attempted to define how this space is affected by the structure of the Russian economy, and the continued high dependence on natural resources.

\section{Reforms dependent on natural resources}

Reform in the Soviet context has been a rather difficult concept. Although the leadership passed legislation on far-reaching reforms, there were often no apparent changes in the functioning of the economic system. ${ }^{5}$ Perhaps the various attempts to reform - although they did not imply important changes in the functioning of the economic system - at least led to some changes in the informal institutions. What seems reasonable to assume is that the underlying informal restrictions were favourable for a change in the formal rules. ${ }^{6}$ If these are interpreted in terms of priorities and the

\footnotetext{
5 Two examples of this are Khruschev's attempts at reform after Stalin's death in the late 1950s, and the so-called Kosygin reform which was introduced in 1965. The Gorbachevian economic reforms met a similar fate.

6 The new laws on individual activities, cooperatives and state enterprises in 1987-88, in combination with glasnost which; among other things, implied a more open economic debate in Soviet journals, presumably contributed to this (see Svensson 2008, for a more thorough analysis of the Soviet economic debate under the perestroika period).
} 
functioning of the economic system, the effect of changes in formal rules would differ depending on past priorities. This line of thought combines Kornai's theory of the shortage economy (Kornai 1980), Davis' research applying the concept of priority to Kornai's theories (Davis 1989) and North's ideas on the role of institutions (North 1990).

Kornai's theory explains that the drive towards expansion (the next level is always higher than the present one) combined with soft budget constraint means that the firm's demand for inputs, including labour, becomes insatiable, and resource utilization becomes inefficient. ${ }^{7}$ Davis modifies this approach by taking the impact of priorities into account. He explains how the priority sectors, such as the military and energy production, in order to ensure that they were not hit by shortages, were favoured in resource allocation. ${ }^{8}$ A high-priority sector was minimally afflicted by shortages and had a soft budget constraint. One should therefore not have expected to observe both pervasive shortages and a soft budget in the same sector (Davis 1989). The soft budget constraint allowed priority sectors to hoard inputs, including labour, thus contributing to increased shortages in the rest of the economy. In contrast, low-priority sectors were characterized by high shortage intensity and a relatively hard budget constraint. ${ }^{9}$

According to this analytical framework, the functioning of the Soviet system and the impact of Soviet priorities steered the economy into a pattern of development that is not easily changed (Sätre 1994). This is

\footnotetext{
7 Kornai's concept of the "soft budget constraint" explains one basic difference between the functioning of capitalist and socialist economies. In a traditional socialist economy, an enterprise has a soft budget constraint. There is no effective financial restriction on its demand for inputs. That is, the budget constraint functions at a loss that does not lead to bankruptcy and the closing of plants.

8 This argument is supported empirically by official Soviet statistics, which show that the shares of industrial employment and investment until the end of the 1980s were relatively higher in heavy industry than in light industry as compared to their respective shares of industrial output.

${ }^{9}$ In the beginning of the $21^{\text {st }}$ century, the fact that more than 40 percent of enterprises in Russia were still experiencing losses without being driven out of business suggests that soft budget constraints still prevail. See Rossiyskiy Statisticheskiy Yezhegodnik (2004) for losses within the different branches in 2003. Rossiya $v$ tsifrakh (2004:133) shows how losses within the different branches on an aggregated level have increased in the period 1992-2003. See Nikitin et al. (2002) for losses month by month in 2001.
} 
reflected in the continued dependence on natural resources which has created a vicious circle as their richness continues to enable the extensive resource-use strategy rather than an increase in productivity. It might even be argued that the strong continued dependence on natural resources has obstructed the creation of well-functioning institutions, which is needed for the development of sectors that are not protected by the state (Tompson 2005).

A continued dependence on natural resources is reflected in the aim of the Putin regime to regain control over oil and gas revenues as a way to strengthen the state and maintain social stability after the chaotic 1990s (Gaddy 2007; Roland 2006; Ericson 2009)..$^{10}$ As the oil and gas resources were renationalized, and while political power was recentralized from the regional level, the Putin administration succeeded in redirecting profits from the oligarchs to the state budget (Treisman 2010). These profits were then used to build up a fund for stabilisation purposes (Appel 2008). ${ }^{11}$ In 2005, the Kremlin launched national projects aimed at developing cooperation between central and regional areas to be implemented by the governors (Chebankova 2010). The projects (also called the presidential programs) financed by the Russian Stabilization Fund, were focused on healthcare, housing, education and agriculture (Smyth et al. 2007). Thus, in broad terms, the purpose of the national strategy for development is, as it appears, to keep control over the oil resources and then use the oil money to encourage socio-economic development in regions. ${ }^{12}$

Low own-source revenues tend to make the local and regional levels highly dependent on the central level. ${ }^{13}$ As energy prices go down, the

${ }^{10}$ In the 1990s, the state security organs and the military sector were radically pared down (Barany 2008). The growth of the state bureaucracy and the salary increases for security agencies under Putin's rule (see Smyth et al. 2007: 126), however, it reflects the priority of regaining control and recentralizing power.

11 According to official figures, the accumulated assets of the Stabilization Fund was more than twenty times higher in 2007 as compared to 2004 (Rossiya $v$ tsifrakh, 2008: 33). The fund, which was established in 2004, was divided into Reserve Fund and National Welfare Fund in 2008.

12 See Kuznetsov et al. (2011: 382). Wegren (2011: 221) argued that financial support from the government had a significant impact on the agrarian sector.

${ }^{13}$ Income and profit tax amount to just about 1.5 percent of total revenues (Thiessen 2006: 203). 
Russian Stabilisation Fund, which was built up by profits from the energy sector, is drained of resources. Consequently, financial funds for local projects are likely to vary depending on fluctuations in energy prices. This shows how state funding available for the local communities is affected by the structure of the Russian economy, and the continued high dependence on natural resources.

As Putin launched the national programs for development, there was suddenly a new possibility for regions to get some extra resources from the upper levels, and the situation at the lowest political level, which had been supposed to rely on an increasing extent of self-financing, suddenly appeared less impossible. Some concrete results of these programs could, for example, be observed in the autumn of 2008, in the region where the field work of this study was carried out. For the first time during the decade, the interviews reflected some belief in a better future. Finally, it was believed that the economic development had started to embrace also ordinary people outside metropolitan areas. However, dark clouds already gathered over them. Projects that had been started with the help of money from the presidential programs were stopped as funds allocated to their implementation had been frozen, directly as a result of the global financial crisis. Nobody seemed to know when and if ongoing projects could be completed. ${ }^{14}$ This provides an illustration as to how local communities are affected by the structure of the Russian economy and the continued high dependence on natural resources. Regions and the lowest political levels will have to deal with the problems. Someone will have to pay the bill for uncompleted projects and ordinary people have to cope with extreme variations in future prospects.

On the other hand, the heavy dependence on world energy prices motivates the government to encourage the development of other branches. This explains the government's goal to diversify the economy and why business-friendly taxes have been adopted in the manufacturing industry and service (Malle 2012). ${ }^{15}$ In effect, this means that the non-strategic

14 Three years later, some of the projects were completed by means of borrowed money, but the cottages that had been built at the construction of a ski tourism resort area three years earlier were still empty.

15 This is in line with repeated statements by Medvedev in which he put emphasis on the urgent need for development of small and medium-sized firms (for example in the 
sectors are given free reign to develop and that they are left to the local level to care about (Duvanova 2011). Policy options at the local political level also vary depending on connections to sectors and the access to the resources of these (Chebankova 2010; Vartapetov 2011). What actually is at stake here is access to not only formal structures, but also to the informal ones (Sakwa 2011). Then there is also the power relation between entrepreneurs and those in charge at different political levels (Duvanova 2011). This also shows how local funding; available through local firms for community development, and local welfare are affected by the structure of the overall Russian economy.

Adhering to North's approach, slow-changing institutions are the reasons why people working in non-priority sectors would be unable to support themselves, and their too low salaries would thus be seen as an integral part of the functioning of the economic system (Gaddy 2007; Kornai 1980; Sätre 1994). ${ }^{16}$ Soft budgets imply that over-employment has survived, while a large part of Russians live with wages that are barely enough to cover basic expenditures (Remington 2011; Rimashevskaya 2010; Soutworth 2006). In manufacturing, many workers had to face a cut in their wages as a consequence of the economic crisis in 2008-2009, due to the fact that management did not reduce the number of employees (Kuznetsov et al. 2011). This also means that local authorities have to deal with the fact that the level of welfare remains low for the vast majority of the local population (Wegren 2011).

\section{Legal changes and the opening up space for agency}

There are a few important changes in legal rules that have contributed to both an increased responsibility and more options as regards possible ways to find solutions. The privatization reforms opened up the possibility

news programme Vremiya on October 29 and 31, 2008). Statements concerning the need of limiting the number of controls and promoting other attempts to remove bureaucratic obstacles have also been noted.

16 The continued dependency on natural resources is thus reflected in employment patterns as well as in relative wages in the 1990s (Sätre 2001). In the first decade of the new century, average wages continued to be highest in the gas industry and oil extraction, and lowest in agriculture and the consumer industry (Remington 2011: 102-103). Rossiya $v$ tsifrakh 2005, pp. 107-109 and 2008, pp. 122-124. 
for individuals to become owners of firms. This meant the possibility of getting access to capital in the form of bank loans, for those who were able to provide security. The privatization of property provided another opportunity of getting capital (Antyuganov and Ivashinenko 1994). One effect of reforms was that it became possible to start one's own firm, something which was not possible for anyone in the Soviet system. In brief, there are various reform measures that each in itself presumably has implied possibilities of obtaining support for local authorities, as there are now private firms and individuals with resources (White 2000). The law on the monetization of social benefits converted in-kind benefits into cash allowances and transferred responsibility for welfare from central to local authorities. ${ }^{17}$ Changes in legal rules have also given rise to a responsibility for self-financing at the local level. ${ }^{18}$ The law on local government removed the previous inconsistency between effective subordination and selfaccountability (Moses 2003; Wilson and Young 2007). Reforms have opened up the space for local initiatives. The institutional approach, however, undermines the question of agency (as formulated among others by Amartya Sen), and leaves; therefore, the question of change unanswered.

\section{Women's strategies: relying on surviving norms versus using new possibilities}

In broad terms, the Soviet system might be characterized by a prioritization of industrial development over social infrastructure. Focusing on the

\footnotetext{
${ }^{17}$ Federal'nyi Zakon No. 122-FZ (Federal Law No. 122-FZ) O vnesenii izmenenii v zakonodatel'nye akty Rossiiskoi Federatsii (On introducing amendments into legislative acts of the Russian Federation), August 22, 2004. A key task was to divide administrative and financial responsibility for providing benefits (l'goty) between the central level and the regions, which means that regions support two-thirds of the recipients. See Wengle and Rassell (2008: 743-744).

18 Federal'nyi Zakon No. 131-FZ (Federal Law No. 131-FZ) Ob obshchikh printsipakh organizatsii mestnogo samoupravlemiia $v$ Rossiiskoi Federatsii (On the general principles of organization of local self-governance in the Russian Federation), October 6, 2003, with the latest amendments introduced on January 1, 2006. A key task involved increased responsibility for self-financing of costs along with the introduction of a fourth level of administration (poselenie) within each community. According to the vice-chairman of a regional duma, this law opened up space for the women's councils (personal interview October 2006).
} 
formal aspect, while industry was completely integrated in the state system of planning, social services were only partially integrated, leaving social issues partly outside of the planned target system (Lapidus 1975). As a result, social issues were to be dealt with in the informal sphere, which meant that actors were left to look for entrepreneurial solutions outside the hierarchical structures for planning under the Soviet system. ${ }^{19}$

The capability approach to analyzing poverty highlights relational aspects rather than incomes or ownership as such (Sen 1984). This means that exchange entitlements are highlighted. Local politicians' ability to promote welfare development thus depends on their ability to transform whatever income or assets they have into useful necessities. As a result of the low priority of female dominated sectors, women had to develop entrepreneurial skills, and these skills have survived from the Soviet system (Sätre 2001, 2010). Women use them in their positions as local politicians with responsibility for social welfare. According to North, this is about survival of responsibilities which take the form of norms connected to entrepreneurship, of having an ability of finding solutions to everyday problems. Reforms have implied that actors get opportunity to occupy 'free social space, to act as they need to have access to some assets, and also to be able to use these assets. Assets are, according to Sen (1984) classified into three categories: resources, including all kinds of capital (also social capital, human capital, cultural capital), rights, and relationships. Therefore, according to this approach, incomes or assets are not enough to overcome poverty; agency in one form or the other is also required. In the following section local politicians' strategies are analyzed by referring to their use of new and old resources, rights and relations, respectively.

\section{The use of new and old resources}

Interviews provided examples of how local politicians use their entrepreneurial skills to compensate for inadequate financial resources. One example was a mayor in a rural community and a director of the department for cultural affairs, both females, trying to encourage entrepreneurship by advising people how to apply for funds for projects (Interview 2003). There

\footnotetext{
19 One sign of this is the low priority that is attributed to social production and social services in the distribution of budgets (Voronin 2002: 53).
} 
were similar activities in another community, found about at later visits, consisting in officials promoting cultural activities, education and local development groups, to make people more self-content, thus imposing a change in mentality of people towards seeing possibilities and taking action (interviews 2011-2012). Politicians are actively taking part in starting cultural organizations, trade unions, and women's councils. They promote the starting of social NGOs, which are used for applying for money from welfare funds at higher levels (Sätre 2013).

The interviews showed how female politicians initiated social projects, cultural activities and small businesses in villages. One example is the "House of Culture" which is dedicated to children from distant villages. One of the lead-off people at the lowest local level initiated the building of a church and obtained sponsors for this purpose (interview, May 2012). A vice administrator said that she had been able to receive support from a charity fund for a youth project directed towards those from troubled families (interviews 2011-2012). This showed local politicians making use of their own human capital, as well as, improving skills of the local population through projects and educational programs.

Interviews also supported the assumption that local authorities are able to mobilise resources of low priority sectors for welfare development in second Russia. It has been argued that the Russian institutional setting is such that businesses are over-regulated (Hitt et al.2004). One problem would be a weak dialogue between the political bodies and their administrative systems (Cuddy and Lijun 2007). If local politicians are able to promote entrepreneurial development, this could; therefore, suggest that they have the skills to resist bureaucratic obstacles in second Russia. Changes in the institutional structure sometimes meant changing local policies frequently, creating "institutional chaos" and introducing significant uncertainty for Russian firms (Hitt et al. 2004). If, however, firms are shown to take a long-term perspective, this might imply that local politicians have the entrepreneurial skills to engage firms in local development thus promoting, what Lindner (2009) defines as "alliance for the locals".

A vice-administrator at the lowest political level; however, said that although the main local entrepreneur supported development in several ways, he also made her own work more difficult as he wanted to decide himself who and what to support: 
'The main local entrepreneur only supports social activities in his own village, local people expect us to provide similar financial help, which we can't: rather than engaging with parents who have drinking problems, we try to create activities for their children outside of their homes, but the main local entrepreneur here does not want to support our activities with youngsters. "Our teenagers have their own hands and feet", he said, while giving support to pensioners' celebrations. But sometimes we get funding for equipment...' (interview May 9, 2012).

The relatively low levels of own-source revenues of local governments reflect the difficulty to extract taxes from local firms and local population (Thiessen 2006) ${ }^{20}$ Earlier research confirms that inadequate and insecure resource funding from the central level incites local politician to make use of whatever social capital there is in the local villages in the form of informal networks (Ledeneva 2008; Shubin 2007). One aspect is that of relying on the tradition of social networks and subsistence entrepreneurship for survival in villages (Granberg 2007; Svensson 2008).

\section{The use of rights}

Earlier research confirms that inadequate allocation of central funds for assigned responsibilities puts limits on their implementation (Thiessen 2006). There is also an uncertainty whether money actually will be allocated from the upper levels according to the rules (Wilson and Young 2007). Nevertheless, reforms have implied that local politicians have rights to take decisions; they have the right to their own budget, to find funding from non-public resources, and make deals with local actors. Interviews gave the impression that local politicians at the municipal level try to use these rights, although hierarchical structures and arbitrary enforcement put a limit on their implementation.

The hierarchical structure was reflected in the interviews with the persons in charge at the lowest political level: "I have had to solve each issue with the particular vice mayor, thus heating and water has to be dealt with

20 This is particularly evident at the regional and local levels, as while the more volatile and unpredictable revenues from profits go to the region, the more secure sources of income go to the state (see further Thiessen 2006). 
through the particular person in the community firm dealing with housing. To get the required money I have to go to the vice-mayor for housing. The old system of receiving salaries in the envelope means that you don't get official incomes and thus no base for collecting taxes."

However, one person in charge also at the lowest political level, emphasized that she felt more powerful with new possibilities of implementing measures than previously. Therefore, although "women continue to solve the problems that fall between the chairs as they did in the Soviet times" there seem to be more options now, and she was proud over her achievements in the recent years. It seemed clear that her job was not really a matter of ideology or political strategies, but about finding practical solutions to ordinary problems of people in their everyday lives.

The difficulties concerning the implementation of the new laws were reflected in interviews with a vice-mayor in 2008. According to her, there is a lack of mechanisms needed for them to work. As regards the law on self-governance, the distribution of responsibility is not clear. The community is presumed to propose budgets for the lowest level of local administration and also how much money these should receive from the regional level as well as from the state. She described how they face the same problem when it comes to the law on the monetisation of benefits, which used to be provided to different categories of the population according to some specific rules. Instead of the former services, people should be compensated in monetary terms. According to the vice-mayor, they have not received proper advice from higher levels on how to distribute such rights practically and how to distribute rights to deserving inhabitants, such as pensioners, war veterans or invalids. Therefore, they have to take decisions themselves at the local level, that is to say, if there are any rights to distribute. A vice-mayor described how unclear rules from the upper levels make any long-term planning difficult (interview May 13, 2012). She liked the idea behind the law on self-governance, but as funding was so poor, hopes were focused on putting some small money from the community budget and getting ten times as much back from the region. Although there were some possibilities to get such extra funding from the upper level for certain projects, she wanted to divert from what she defined as 'a slumpwise development', by getting less dependent on central funding.

Contradictory rules also open up for an arbitrary enforcement. There were different stories heard concerning local administrators being fined; as 
they believed arbitrarily, and how they did not bother to go to court about it. One of the administrators at the lowest political administration told me how he was fined as he had allocated a flat to a young person with difficult life conditions without permission from above (interview May 12, 2012). Nevertheless, the same administrator emphasized how important was the fact that those in his position were active in many ways, also working actively with the state and regional levels. The conclusion to be made is that despite tendencies of surviving hierarchical structures and arbitrary enforcement of legal rules, there seems to be a view that local politicians do have space for different kinds of actions. They are able to use their rights, provided by reforms, in second Russia. Therefore, they may also contribute to the local development, which possibly has consequences in the wider context.

\section{The use of relations}

A politician at the lowest political level described how she had to find ways to get hold of resources by asking for funds from higher political levels, by asking the local entrepreneurs for support, or by mobilizing local people to either contribute on a voluntary basis, or to engage in a process of bargaining. In effect, what she described was how the decentralization affected her own working situation and how difficult it can be at times. ${ }^{21}$ A vice-mayor emphasized how she 'used the different bargaining strategies that she had learned from her grandmother; when to be a diplomat, and how to avoid problems'.

\section{Strategies towards firms}

Based on interviews, some strategies towards firms could be identified. One is to rely on voluntary contributions of firms, either as a result of the initiatives of firms themselves or as a result of "begging practices". The fact that most taxes go to the federal budget combined with practical difficulties to collect taxes, encourages local authorities to tolerate tax evasion in exchange for investments that stay in the region (Polichuk

\footnotetext{
2008.

${ }^{21}$ Interview with the head of the lowest level of political administration, 28 October
} 
2009). ${ }^{22}$ Rather than trying to enforce tax payments, local authorities count on the contribution of local businesses to local development. In 2003, a local mayor admitted that he can 'look the other way' if local entrepreneurs create new work places, but he also said he can 'look the other way' if small businesses violate rules as he is 'satisfied if people find ways to support themselves and hopefully some others around them' (interview, December 2003). There is a mutual interest as it is important for firms to have a working infrastructure, which can be linked to surviving norms of employers' paternalism, although investments tend to be earmarked towards their own interest rather than to the priorities of local politicians (Granberg 2007). Secondly, local business developers might prefer to be seen as "good sons or daughters of their local communities" than as "greedy capitalists” (see Sätre 2013).

There are also strategies based on donations to charity and sports by local businesses (Chebankova 2011: 137-38). One example is the building of churches. Another example is how one entrepreneur finances various local projects within his native village. While he provides part of the financing for a church and a new school; on the one hand, he finances various building projects such as a sport hall, the renovation of the house of culture and the construction of a fountain and the like. On the other hand, he provides social contributions, such as housing or transportation to work, child care and child benefits for his employees.

An entrepreneur within the tourism business said that she had to choose what she wanted to support, as she could not contribute in all spheres. She has chosen ski related activities for children. The means that she would voluntarily contribute in a way that facilitates the good performance of her work in her public employment as a ski teacher/trainer. Another example is provided by the contribution of local firms to the celebration of the Victory Day, the Old People's Day, and how they contribute with coffee and presents at concerts.

The "begging practices" include asking the more prominent male entrepreneurs to provide work places and social services for their local villages. ${ }^{23}$ The strategy seems to serve the purpose of making a contract

\footnotetext{
22 The increased responsibility at the local level is reflected in an increase in the number of employees at local government bodies (Rossiya $v$ tsifrakh 2008: 60).

${ }^{23}$ Interviews 9 May; 11 May and 12 May, 2012.
} 
with solvent entrepreneurs to support particular villages with some specific social services, such as housing or support to funerals, or job creation. ${ }^{24}$ A vice-mayor described how they advocated extending the norm from Soviet times to the local community, to rely on paternalistic employees, reproducing the role of kolchozes in the time of Soviet rural society (see Melin ed. 2005). ${ }^{25}$ An entrepreneur within the tourism business provided information on how the local vice-mayor expected her to contribute to the community in different ways free of charge. Interviews showed that this strategy was used towards the larger firms (interviewed vice-mayors 2005; 2008). Some years later however, a vice-mayor admitted that she really wanted to stop 'the habit of begging', putting her efforts of catching their genuine interests in participation in developing local projects instead (interviews with vice-mayor $2011 ; 2012$ ).

A second strategy is to rely on informal taxes (Gaddy 2007; Lazareva 2009). Interviews indicated that this strategy was used towards the smaller firms. If local authorities are able to successfully implement informal taxation strategies, this shows that there are economically viable enterprises at the local level. And, if local authorities are able to tax local enterprises, this suggests that they have some power in their hands vis-à-vis these enterprises. Another form of informal taxation is when local authorities simply do not pay for services provided by local enterprises. ${ }^{26}$

A third strategy is to rely on collaboration with firms. Interviews indicated that this strategy was used towards the larger firms. In 2003, a mayor said that since it was easier to have to deal with just a few strong firms, he promoted a process in which larger firms took over the smaller ones. The existence of partnership agreements, in turn, indicates that

\footnotetext{
${ }^{24}$ According to Wengle and Rassell (2008: 741), in 2002-3 the value of in-kind benefits represented 10-15 percent of the income of poor households receiving l'goty, while the figure is likely to have been much higher in the 1990s. See Lazareva (2009: 9-32) on the procedures for transferring assets from firms to municipalities, and also on the joint usage and financing of transferred assets.

25 The surviving habit of big firms to take social responsibility for their employees and finance social tasks that the community does not have the capacity or resources to handle is confirmed by the work of other scholars (Granberg 2007; Shubin 2007; Lazareva 2009).

${ }^{26}$ One example is that local service providers of utilities and municipal transport systems often had to bear the costs of providing discounts to eligible benefit recipients, without being compensated by the authorities (Wengle and Rassell 2008: 742).
} 
local authorities should have something to offer local enterprises, thus potentially contributing to their economic development. ${ }^{27}$ In interviews from 2003 one could hear about how politicians traded forests for promises to create work places. In 2012, the vice-mayor described how they focused on developing common projects that would benefit the community as well as the individual entrepreneur. ${ }^{28}$ The most important initiative was the collaboration with one entrepreneur to build up a ski tourism centre financed largely by central funds. She said she believed in large projects, which can be taken as a fourth strategy. The idea was to achieve the status of national park for the area around the skiing centre and to attract small entrepreneurs to build up activities with cultural orientation around it.

\section{Combining politics, unpaid work and contributions from the rich}

Many regular visits during a period of ten years showed that many development trends were underway in some places. Still, there were also places which were not doing well at all. A female politician, who has been in charge at the lowest political level for twenty years, provided one illustration of what the situation might look like. In the morning she receives visitors from the local population. They come to see her when they have complaints about practical matters. If the budget is not enough, she uses her own salary. She writes documents confirming that 'somebody should be entitled to social support or needs transport to the hospital'. In 2011, she said she spent time in meetings with the village council to work out ideas for applications or she was "begging for help" from the community level or from the only firm in this village, the vodka factory (interview May 2011). The following year the situation became even worse as the vodka factory was closing down. Similar stories were told in other remote villages... There was a local administrator who was crying over the miserable situation in her villages, and she had already spent her own salary on urgent matters.

A local politician said in 2008 that the standard of living was considerably better than just a couple of years ago, although differences on the lowest

27 One example is how officers barter the labour of conscripts for goods or services with local politicians (Barany 2008: 597).

28 The same person is in control in most businesses, and there is another who is still in charge within the timber business, although there is a new name as well. 
political level were wide within the same community. "Some do not have any money of their own due to the lack of firms. This means that they have to live just on subsidies which are inadequate."

In such cases, strategies based on voluntary work are particularly relevant. Such strategies seem to largely rely on women's double responsibilities (Kay 2011; Salmenniemi 2008). Being responsible for social welfare at all the different political levels, and; simultaneously, being active in the corresponding level of the women's councils, these women take major responsibilities for making up for deficiencies of the state in this sphere. ${ }^{29}$ Efforts are required to prepare applications for grants from the different programs available from the federal and regional levels. ${ }^{30}$ This means time for lobbying, persuading and making serious preparations to get money from higher political levels.'The same people are involved in all the NGOs; these are more directly targeting towards helping particular groups. Such common work has resulted in a sports hall, the repair of water sources, and local bridges...' (interview May 2011). A vice-mayor, asked about collaboration between the local administration, social security and NGOs, mentioned five women, who represent NGOs with roots from the Soviet time. As one of the administrators at the lower level put it: 'As the state cannot apply for funding from the national programs we have to mobilize the NGOs. This is facilitated by working in the villages, where everybody knows each other; the same people are involved in all the NGOs' (interview, village, May 2011).

\section{Conclusions}

This paper is focused on how the survival of women's entrepreneurial skills from the handling of shortcomings in the Soviet system is reflected in their strategies for social development in local contexts in contemporary Russia. They have relied on surviving norms from the Soviet time, while

\footnotetext{
29 The same women are also the ones holding corresponding positions in the women's council. Thus, for example, women with political positions on the regional level hold similar positions in the regional women's council. The situation is similar at the local level and within villages. Then they all go to the region's main town for the annual assembly (interviews with three female politicians at the lowest level of political administration, 24-25 October 2008)

${ }^{30}$ Interview with a vice-mayor 27 October, 2008.
} 
also developing strategies based on new possibilities, arising as a result of reforms. Therefore, they have contributed to strengthen norms from the Soviet time which are still important for everyday survival. Thus, women in local politics base their strategies on paternalist behaviour and social responsibility of firms, social mothers, and on a strong influence of central government, which; in turn, is connected to the resource-based development. Their strategies also utilize some new trends, indicating a break with the past: writing applications, agency for changing mentalities of local actors as well as that of the poor, stimulating small-scale entrepreneurship and implementing youth projects. Many politicians work for their own ideas, rather than just implementing directives from above. They work on the basis of both formal and informal solutions. Women who were active during the soviet system were entrepreneurial in order to implement directives from the upper levels. This phenomenon has survived as responsibilities are still assigned to them not in parity with allocation of resources from above, while possibilities to collect local taxes are inadequate. The strategies involved collaboration with local firms and/or organizations, including NGOs and voluntary work. Other possibilities included informal taxation and begging. To return to North's analytical framework, what is involved here is the survival of entrepreneurial behavior necessary to deal with shortcomings resulting from the low-priority status of social issues in the Soviet system.

The study provided support for the view that there is a widening gap between communities as well as within communities, depending on resources and the ability to use them. Economic recovery in the 2010s means money into the state budget, some of which is earmarked for social issues. This is given to local authorities directly for certain earmarked tasks as well as in an indirect way, where they have to write project applications in order to get money. Although social policy; to some extent, continues to be financed by the state it is organized in a partly new way.

While the leadership decides about reforms, setting new formal rules, local politicians develop their own routines and strategies. Being responsible for organising social welfare, female politicians described how they use different strategies. Therefore, solutions are likely to be more heterogeneous than before. It was indicated that female politicians who are responsible for social affairs have to negotiate with local firms and voluntary organizations, 
beg, or find solutions in other way. On the other hand, this study also showed that women in charge feel more powerful with new possibilities to implement measures than before. As it appears, one important explanation to variations within communities could be the existence of large local firms. This means, however, a risk that it is rich entrepreneurs, rather than the local politicians responsible for social affairs, who decide how to distribute social welfare at the local level. The study, on the other hand, indicated that an increased access to Russian funds through project applications when oil prices are high might decrease the dependency on local firms. Thus, as the access to such financing opportunities seems to be highly dependent on oil prices, the dependency of local politicians on local entrepreneurs is also likely to fluctuate with oil prices.

The study provided information about how it happens, how female local politicians continue to take responsibility for social welfare, how they react, and how they find and use new possibilities. The empirical material supported the broad picture and the finding that Soviet culture taught people to find solutions which are needed in second Russia. "The agency aspect" needs to be added to institutional analysis frameworks as expressed by North (1990) in order to see how norms influence social development in second Russia.

\section{References}

Antyuganov, V. and Ivashinenko, N., 1994. Privatizatsiya i bankrotstvo [Privatization and bankruptcy], VVKTS.

Appel, H., 2008. 'Is it Putin or Is It Oil? Explaining Russia’s Fiscal Recovery', PostSoviet Affairs, Vol. 24 (4): 301-323.

Chebankova, E., 2010. 'Public and Private Cycles of Socio-Political Life in Putin's Russia', Post-Soviet Affairs, Vol. 26 (2):121-148.

Clements, B. E., 1992. 'The Utopianism of the Zhenotdel', Slavic Review, Vol. 51 (3): 485-496.

Cuddy, M. and Qian L., 2007. 'The Rural Economy in China and Russia - What is Different? Is There a Lesson for Russia?', Econ Change, Vol. 40: 157-187.

Davis, C., 1989. Priority and the shortage model: the medical system in the socialist economy. In: Davis, C. and Charemza, W. (eds.), Models of Disequilibrium and Shortage in Centrally Planned Economies. London, UK: Chapman \& Hall. 
Duvanova, D. S., 2011. 'Firm Lobbying versus Sectoral Organization: The Analysis of Business-State Relations in Post-Communist Russia, Post-Soviet Affairs, Vol. 27 (2): 387-409.

Ericson, R., 2009. 'The Russian Economy in the Year 2008: Testing the "Market Economy"', Post-Soviet Affairs, Vol. 25 (3): 209-231.

Gaddy, C. G., 2007. 'The Russian Economy in the Year 2006', Post-Soviet Affairs, Vol. 21 (1): 38-49.

Granberg, L., 2007. Rural Paths in Russia, In: Heinonen, M., Nikula, J, Kopoteva, I. and Granberg, L. (eds), Reflecting Transformation in Post-Socialist Rural Areas, Cambridge: Scholars Publishing, pp. 49-62.

Hitt, M., 2004. 'The Institutional Effects on Strategic Alliance Partner Selection in Transition Economics: China vs. Russia, Organization Science, Vol. 15 (2): 173-185.

Iarskaia-Smirnova, E. and Romanov, P., 2002. 'A Salary is not Important Here: The Professionalization of Social Work in Contemporary Russia, Social Policy \& Administration, Vol. 36 (2): 123-141.

Kay, R., 2011. '(Un)caring Communities: Processes of Marginalisation and Access to Formal and Informal Care and Assistance in Rural Russia, Journal of Rural Studies, Vol. 27 (1): 45-53.

Khlinskaya Rockhill, E., 2010. Lost to the State. Family Discontinuity, Social Orphanhood and Residential Care in the Russian Far East. New York and Oxford: Berghahn Books.

Kornai, J., 1980. Economics of Shortage, Amsterdam, Netherlands: North Holland.

Kulmala, M., 2010. 'Women Rule this Country: Womens Community Organizing and Care in Rural Karelia, The Anthropology of East Europe Review, Vol. 28 (2): 164-184.

Kuznetsov, B., Dolgopyatova, T., Golikova, V., Yakovlev, A. and Yasin, Y., 2011, 'Russian Manufacturing Revisited: Industrial Enterprises at the Start of the Crisis', Post-Soviet Affairs, 27 (4): 366-386.

Lapidus, Gail W., 1975. 'Political Mobilization, Participation, and Leadership: Women in Politics', Comparative Politics 8 (1): 90-118.

Lazareva, O., 2009. Labour Market Outcomes During the Russian Transition, Stockholm School of Economics (dissertation).

Ledeneva, A., 2008. 'Telephone Justice in Russia', Post-Soviet Affairs, Vol. 24 (4): 324-350.

Lindner, P., 2009. 'Localising Privatization, disconnecting locales - Mechanisms of disintegration in post-socialist rural Russia', Geoforum, Vol. 38: 494-504. 
Malle, S., 2012. 'Policy Challenges of Russia's Post-Crisis Economy', Post-Soviet Affairs, Vol. (28) 1: 66-110.

Melin, H. (ed.), 2005. Social Structure, Public Space and Civil Society in Karelia, University of Helsinki: Kikimora Publications 34.

Moses, J. C., 2008. 'Who Has Led Russia? Russian Regional Political Elites, 19542006', Europe-Asia Studies, Vol. 60 (1): 1-24.

Nikitin, G. G., Dulskaya, N. N., Burko, I. Yo. and Nikitin, A. G., 2002. 'Kozyaistvennaya deyatelnost predpriyatii' [The economic activity of an enterprise], EKO, Vol. 6: 25-39.

North, D., 1990. Institutions, Institutional Change and Economic Performance. Cambridge: Cambridge University Press.

Polichuk, L., 2009. 'Corporate Social Responsibility vs. Government Regulation: Institutional Analysis with an Application to Russia. Working Paper WP10/2009/01, Moscow State University - Higher School of Economics.

Remington, T., 2011. 'The Russian Middle Class as Policy Objective', Post-Soviet Affairs, Vol. 27 (2): 97-120.

Rimashevskaya, N. M., 2010. 'Riski bednosti v sovremennoi Rossii' [Risks of poverty in modern Russia], Narodonaselenie, Vol. 2 (48): 4-9.

Roland, G., 2006. 'The Russian Economy in the Year 2005', Post-Soviet Affairs, Vol. 22 (1): 90-98.

Rossiya $v$ Tsifrakh [Russia in figures], (various years), Goskomstat Rossii, Moscow.

Rossiyskiy Statisticheskiy Yezhegodnik [Russian Statistical Yearbook], (various years) Goskomstat Rossii, Moscow.

Sakwa, R., 2010. 'The Dual State in Russia', Post-Soviet Affairs, Vol. 26 (3): 185206.

Salmenniemi, S., 2008. Democratization and Gender in Contemporary Russia, London \& New York: Routledge.

Sen, A., 1984. Resources, Values and Development, Oxford: Basil Blackwell Publisher Ltd.

Shanin, T. and Alexander, N., 2012. Vtoraya Rossiya: Differentsiatsiya i Camaorganizatsiya [Second Russia: differentiation and self-organization]. Moskva: Izdatelstvo dom 'Delo'.

Shevchenko, J., 2002. 'Who Cares about Women's Problems? Female Legislators in the 1995 and 1999 Russian State Dumas', Europe-Asia Studies, Vol. 54 (8): 1201-1222.

Shubin, S., 2007. 'Networked Poverty in Rural Russia', Europe-Asia Studies, Vol. 59 (4): 591-620. 
Smyth, R., Lowry A. and Wilkening B., 2007. 'Engineering Victory: Institutional Reform, Informal Institutions, and the Formation of a Hegemonic Party Regime in the Russian Federation, Post-Soviet Affairs, Vol. 23 (2): 118-137.

Soutworth, C., 2006. 'The Dacha Debate. Household Agriculture and Labor Markets in Post-Socialist Russia, Rural Sociology; 71 (3): 451-478.

Svensson, B., 2008. Seven years that shook Soviet economic and social thinking. Reflections on the revolution in communist economics 1985-91, Stockholm Studies in Economic History No. 55, Stockholm University (dissertation).

Sätre, A-M., 1994. Environmental Problems in the Shortage Economy: The Legacy of Soviet Environmental Policy, Aldershot and Brookfield USA: Edward Elgar Publishing Limited.

Sätre A.-M., 2001. 'Women's and Men's Work in Transitional Russia: Legacies of the Soviet System', Post-Soviet Affairs, Vol. 17 (1): 56-79.

Sätre, A.-M., 2007. Vild kapitalism och gammal byråkrati. Om småföretagare $i$ Ryssland [Wild capitalism and old bureaucracy. On small entrepreneurs in Russia]. Nøhaven Danmark: Premiss förlag.

Sätre, A.-M., 2010. Women's Work in transitional Russia: Women's Strategies for Entrepreneurship and Survival in Russian Regions, in: Kangaspuro, M. Nikula, J. \& Stodolsky, I. (eds.) Perestroika: Process and Consequences, Helsinki: Finnish Literary Society.

Sätre, A.-M., 2012. Gendered Experiences in Russian Entrepreneurship, Family and Social Activities. In: Carlbäck, H., Gradskova, I. and Kravchenko Z. (eds.), And They All Lived Happily Ever After? Norms and Everyday Practices of Family and Parenthood in Russia and Eastern Europe, CEU press, pp. 297-318.

Sätre, A.-M., 2013. Women's Work, Political Strategies and Survival in rural Russia. In: Simmons, C. (ed.) Post-Communist Transition and Women's Agency: Russia and the "Near Abroad", Dordrecht: ROL Publishers.

Thiessen, U., 2006. 'Fiscal Federalism in Russia: Theory, Comparisons, Evaluations', Post-Soviet Affairs, Vol. 22 (3): 189-224.

Tompson, W., 2005. 'The Political Implications of Russia's Resource-Based Economy', Post-Soviet Affairs, Vol. 21 (4): 335-359.

Treisman, D., 2010. 'Loans for Share' Revisited', Post-Soviet Affairs, Vol. 26 (3): 207-227.

Vartapetov, K., 2011. 'Russian fiscal federalism under stress: federal support of regions during the global financial crisis', Eurasian geography and economics, Vol. 52 (4): 529-542. 
Voronin, Yo., 2002. 'Prioritety byodzhetnoi politiki' [Priority in budget politics], Ekonomist, Vol. 7: 52-57.

Wegren, K., O’Brien, D. and Patsiorkovski, V., 2003. 'Russia's Rural Unemployed, Europe-Asia Studies, Vol. 55 (6): 847-867.

Wegren, K., 2011. 'Private farming in Russia: An Emerging Success?', Post-Soviet Affairs, Vol. 26 (3): 211-240.

Wengle, S. and Rasell, M., 2008. 'The Monetisation of L'goty: Changing Patterns of Welfare Politics and Provision in Russia, Europe-Asia Studies, Vol. 60 (5): 739-756.

White, A., 2000. 'Social Change in Provincial Russia: The Intelligentsia in a Raion Centre', Europe-Asia Studies, Vol. 52 (4): 677-694.

Yates, S., 2004. Living with Poverty in Post-Soviet Russia: Social Perspectives on Urban Development, London School of Economic and Political Science (doctoral thesis). 